\title{
Effects of taurine supplementation in low fish meal diets for red seabream (Pagrus major) in low water temperature season
}

\author{
G. L. B. E. Gunathilaka' ${ }^{1}$, Min-Gi Kim', Chorong Lee ${ }^{1}$, Jaehyeong Shin ${ }^{1}$, Bong-Joo Lee ${ }^{2}$ and Kyeong-Jun Lee ${ }^{1,3^{*}}$ (D)
}

\begin{abstract}
Background: Taurine is a conditional essential amino acid for fish. A study was conducted to investigate the compensating effect of supplemental taurine in diets for red seabream (Pagrus major) on impaired growth performance by fish meal (FM) replacement with soybean meal (SM) at low water temperature $\left(14.15 \pm 1.95^{\circ} \mathrm{C}\right)$.

Methods: A FM-based diet was considered as a high FM diet and three other experimental diets were formulated to replace FM with SM by 20,35, or 50\% (HFM, SM20, SM35, or SM50, respectively) without taurine and other four diets were formulated by adding 1\% taurine to the diets (HFM-T, SM20-T, SM35-T, or SM50-T, respectively). Triplicate groups of fish ( $108.9 \pm 1.58 \mathrm{~g} /$ fish) were distributed into 24 polyvinyl circular tanks $(215 \mathrm{~L})$ with 20 fish per tank and fed one of the diets to satiation for 20 weeks.

Results: Growth performance and feed utilization of red seabream were significantly improved by the dietary taurine supplementation. SM20-T and SM35-T diets increased fish growth that are comparable to HFM diet. Feed intake, feed conversion ratio, and protein efficiency ratio of fish fed SM20-T and SM35-T diets were not significantly different from those of HFM group. Dietary taurine supplementation in each FM replaced group numerically increased innate immunity of the fish. Lysozyme and superoxide dismutase activities were significantly decreased in fish fed SM35, SM50, and SM50-T diets compared to those of fish fed HFM diet while they were not significantly lower in SM20, SM20-T, SM35, and SM35-T groups. Glutathione peroxidase activity was significantly lower in fish group fed SM50 diet while SM50-T group did not significantly lower compared to that of HFM group. The relative expression level of hepatic IGF-1 mRNA was improved in fish fed taurine-supplemented diets compared to their respective SM diets.
\end{abstract}

Conclusions: Growth performance and feed utilization of red seabream can be accelerated or restored by $1 \%$ taurine supplementation when they are fed high level of SM up to 35\% in diets during low water temperature season.

Keywords: Taurine, Red seabream, Soybean meal, Low fishmeal, Hepatic IGF-1, Growth performance, Innate immunity

\footnotetext{
* Correspondence: kjlee@jejunu.ac.kr

${ }^{1}$ Department of Marine Life Sciences, Jeju National University, Jeju 63243,

South Korea

${ }^{3}$ Marine Science Institute, Jeju National University, Jeju, Self-Governing

Province 63333, South Korea

Full list of author information is available at the end of the article
}

(c) The Author(s). 2019 Open Access This article is distributed under the terms of the Creative Commons Attribution 4.0 International License (http://creativecommons.org/licenses/by/4.0/), which permits unrestricted use, distribution, and reproduction in any medium, provided you give appropriate credit to the original author(s) and the source, provide a link to the Creative Commons license, and indicate if changes were made. The Creative Commons Public Domain Dedication waiver (http://creativecommons.org/publicdomain/zero/1.0/) applies to the data made available in this article, unless otherwise stated. 


\section{Introduction}

Taurine (2-aminoethanesulfonic acid) is an amino acid which contains acidic sulfonate group and a basic amino acid group. Taurine exists naturally in animals in higher concentrations than other amino acids (Brosnan and Brosnan 2006; Salze and Davis 2015). Many studies proved that taurine is an essential nutrient for fish (Takagi et al. 2008; Lim et al. 2013; El-Sayed2014; Salze and Davis 2015) and involved in bile acid metabolism of fish (Goto et al. 1996, 2017). Therefore, taurine enhances lipid metabolism of fish and improves the absorption of fat-soluble vitamins (Kim et al. 2008; El-Sayed2014). A study conducted by Park et al. (2002) indicated that dietary taurine was involved in a metabolism of sulfur amino acids of juvenile Japanese flounder (Paralichthys olivaceus). Kim et al. (2005) found that feed intake of Japanese flounder was enhanced by a dietary taurine supplementation. Martinez et al. (2004) indicated that $0.2 \%$ taurine was required for better growth performance of juvenile seabass (Dicentrarchus labrax). In juvenile yellow catfish (Pelteobagrus fulvidraco) diet, 1.09\% taurine supplementation was essential for the best growth, immunity, and disease resistance (Li et al. 2016). Growth and reproduction of yellowtail (Seriola quinqueradiata) were improved by a dietary taurine supplementation (Matsunari et al. 2006). According to these evidences, therefore, it is obvious that dietary taurine supplementation enables to provide a wide range of beneficial effects in many fishes. However, it has been reported that some fish species are unable to synthesize taurine or some fish species are able to synthesize it but lower amount than their requirements (Salze and Davis 2015).

Production of low fish meal (LFM) diets is an essential practice for the sustainable aquaculture as the price and demand of fish meal (FM) have been increased for the past decades and its supply is not predicted to increase. Numerous studies have been conducted to formulate and investigate LFM diets with plant-based ingredients due to vast availability and low price. Soybean meal (SM) contains high protein content and amino acids which are readily available and acceptable by most of the cultured fish species (Titgemeyer et al. 1989; Lim and Akiyama 1992). Many studies have been conducted to replace FM with SM and substantial results reported for many fish species (Hernandez et al. 2007; Lim and Lee 2008; Antonopoulou et al. 2017; Kumar et al. 2017; Zhang et al. 2018a). The impaired growth performance was the identified difficulty which could not be overcome even though all the nutritional requirements were fulfilled in the plant protein-based diets (Gaylord et al. 2007). Therefore, in order to restore FM effects in high SM diets, taurine has been used as a dietary supplement in diets for many fish species and successful results has been observed. In common dentex (Dentex dentex), 25\%
FM was successfully replaced with soy protein when $0.2 \%$ taurine was supplemented to the diet (Chatzifotis et al. 2008). Hien et al. (2015) demonstrated that $40 \%$ FM was successfully replaced for snakehead (Channa spp.) with $1 \%$ taurine supplementation. Also, Zhang et al. (2018b) successfully replaced FM up to 50\% with $\mathrm{SM}$ and $0.1 \%$ taurine supplementation without sacrificing growth, immunity, and digestive enzyme activity of juvenile black carp (Mylopharyngodon piceus).

Red seabream (Pagrus major) is widely cultured fish species in the East Asian regions. Taurine has been tested in red seabream diet and a number of beneficial effects were observed in many studies. Growth and development were accelerated in red seabream larvae fed taurine-enriched rotifers (Chen et al. 2005; Kim et al. 2016). Also, dietary taurine supplementation alleviates chemical toxicity and bioaccumulation in red seabream (Hano et al. 2017a; Hano et al. 2017b). Several studies showed that taurine deficiency causes the green liver syndrome of fishes including red seabream (Takagi et al. 2008, 2011). Additionally, taurine supplementation was reported to have an ability to accelerate growth of red seabream when they were fed a LFM diet (Takagi et al. 2006; Takagi et al. 2010). It was documented that red seabream hardly synthesize taurine in vivo (Takeuchi et al. 2001). Consequently, several researches were conducted to find an optimum taurine level in diets for red seabream. Matsunari et al. (2008) reported that taurine requirement for juvenile red seabream is $0.5 \%$ in a casein-based diet. Recently, Salze and Davis (2015) reported that taurine requirement of red seabream varies with their growth stages and main protein sources used in their diets, and it ranges between 0.5 and $2.0 \%$.

Water temperature is an important environmental factor which controls the growth, metabolic rate, and food consumption of poikilothermic animals including fish (Brett 1971; Jensen et al. 2000). Performance of fish under low water temperature has been examined (Öz et al. 2017, Öz et al. 2018a, b, c). Earlier, Woo (1990) reported that metabolic rate of red seabream was changed by water temperature. However, effects of low water temperature on red seabreams were not well studied up to date. Therefore, this study was conducted to evaluate the effects of taurine supplementation in diets for red seabreams when graded levels of FM were replaced by $\mathrm{SM}$ in the diets during the low water temperature season.

\section{Materials and methods Experimental diets}

Four diets were formulated to replace FM with soybean meal by $0,20,30$, or $40 \%$ (designated as HFM, SM20, SM35, or SM50, respectively) without taurine and with $1.0 \%$ taurine addition (designated as HFM-T, SM20-T, 
SM35-T, or SM50-T, respectively). Dry ingredients were thoroughly mixed in a mixer and extruded through a pelletizer machine (SP-50, Gum Gang Engineering, Daegu, Korea) in a proper size. Then, the pellets were air-dried at $25^{\circ} \mathrm{C}$ for $12 \mathrm{~h}$ and stored at $-20^{\circ} \mathrm{C}$ until use (Table 1).

\section{Feeding trial}

Red seabream was acclimatized to the experimental conditions and facilities for 2 weeks before the feeding trial. A commercial diet was fed to the fish during the period. After the period, randomly selected 480 fish (initial mean body weight, $108.9 \pm 1.58 \mathrm{~g}$ ) were distributed into 24. $215 \mathrm{~L}$ capacity polyvinyl circular tanks with 20 fish per tank. Those tanks were supplied with sand-filtered seawater at a flow rate of $3 \mathrm{~L} \mathrm{~min}^{-1}$ and aerated to maintain sufficient dissolved oxygen level. Triplicate groups of fish were fed one of the experimental diets until satiation (twice a day, 09:00 and 18:00 h) for 20 weeks. Remaining feeds in the tanks were collected 30 min after feeding and reweighed to determine feed intake. Water temperature was dependent on the natural water temperature and maintained at $14.2 \pm 1.95{ }^{\circ} \mathrm{C}$ during the feeding trial in the winter time.

\section{Sample collection and analyses}

Fish in each tank were bulk weighted and counted to calculate growth and feed utilization parameters at the end of 20 weeks of the feeding trial. Three fish per tank were sampled and stored at $-20^{\circ} \mathrm{C}$ for further wholebody proximate composition analysis. Blood samples were taken from randomly captured four fish per tank. Fish were anesthetized with a 2-phenoxyethanol solution (200 ppm) before the collection of blood samples. The whole blood samples were used for analyses of hematocrit, hemoglobin, and respiratory burst activity. The plasma was separated from the whole bloods and used for determination of immunoglobulin level and biochemical parameters. Another set of blood samples were taken from four fish in each tank using non-heparinized

Table 1 Formulation and proximate composition of the eight experimental diets for red seabream (\%, dry matter basis)

\begin{tabular}{|c|c|c|c|c|c|c|c|c|}
\hline & HFM & HFM-T & SM20 & SM20-T & SM35 & SM35-T & SM50 & SM50-T \\
\hline Chile fish meal & 45.00 & 45.00 & 36.00 & 36.00 & 29.25 & 29.25 & 22.50 & 22.50 \\
\hline Soybean meal & 0.00 & 0.00 & 13.00 & 13.00 & 23.03 & 23.03 & 33.00 & 33.00 \\
\hline Corn gluten meal & 10.00 & 10.00 & 10.00 & 10.00 & 10.00 & 10.00 & 10.00 & 10.00 \\
\hline WGM $^{1}$ & 8.00 & 8.00 & 8.00 & 8.00 & 8.00 & 8.00 & 8.00 & 8.00 \\
\hline Wheat flour & 22.00 & 22.00 & 16.90 & 16.90 & 13.41 & 13.41 & 10.07 & 10.07 \\
\hline Fish oil & 4.50 & 4.50 & 4.90 & 4.90 & 5.20 & 5.20 & 5.50 & 5.50 \\
\hline Soybean oil & 4.50 & 4.50 & 4.90 & 4.90 & 5.20 & 5.20 & 5.50 & 5.50 \\
\hline Mineral $\mathrm{mix}^{2}$ & 1.00 & 1.00 & 1.00 & 1.00 & 1.00 & 1.00 & 1.00 & 1.00 \\
\hline Vitamin $\mathrm{mix}^{3}$ & 1.00 & 1.00 & 1.00 & 1.00 & 1.00 & 1.00 & 1.00 & 1.00 \\
\hline Cellulose & 1.00 & 0.00 & 1.00 & 0.00 & 1.00 & 0.00 & 1.00 & 0.00 \\
\hline Choline chloride & 0.50 & 0.50 & 0.50 & 0.50 & 0.50 & 0.50 & 0.50 & 0.50 \\
\hline Starch & 2.50 & 2.50 & 1.90 & 1.90 & 1.00 & 1.00 & 0.00 & 0.00 \\
\hline Lysine & 0.00 & 0.00 & 0.15 & 0.15 & 0.20 & 0.20 & 0.25 & 0.25 \\
\hline Methionine & 0.00 & 0.00 & 0.10 & 0.10 & 0.15 & 0.15 & 0.20 & 0.20 \\
\hline Threonine & 0.00 & 0.00 & 0.05 & 0.05 & 0.06 & 0.06 & 0.08 & 0.08 \\
\hline Taurine & 0.00 & 1.00 & 0.00 & 1.00 & 0.00 & 1.00 & 0.00 & 1.00 \\
\hline $\mathrm{DCP}{ }^{4}$ & 0.00 & 0.00 & 0.60 & 0.60 & 1.00 & 1.00 & 1.40 & 1.40 \\
\hline \multicolumn{9}{|c|}{ Chemical composition ( $\%$ dry matter) } \\
\hline Moisture & 6.15 & 6.10 & 6.48 & 6.43 & 6.78 & 6.73 & 7.08 & 7.03 \\
\hline Protein & 48.4 & 48.2 & 48.7 & 48.5 & 48.9 & 48.7 & 48.6 & 48.6 \\
\hline Lipid & 15.1 & 15.3 & 15.4 & 15.4 & 15.6 & 15.3 & 15.7 & 15.6 \\
\hline Ash & 9.71 & 9.84 & 9.36 & 9.47 & 9.21 & 9.24 & 8.96 & 8.74 \\
\hline
\end{tabular}

${ }^{1}$ Wheat gluten meal

${ }^{2}$ Mineral premix (g kg ${ }^{-1}$ of mixture): $\mathrm{MgSO}_{4} .7 \mathrm{H}_{2} \mathrm{O}, 80.0 ; \mathrm{NaH}_{2} \mathrm{PO}_{4} .2 \mathrm{H}_{2} \mathrm{O}, 370.0 ; \mathrm{KCl}, 130.0$; Ferric citrate, 40.0; $\mathrm{ZnSO}_{4} .7 \mathrm{H}_{2} \mathrm{O}, 20.0 ; \mathrm{Ca}^{-l a c t a t e}, 356.5 ; \mathrm{CuCl}, 0.2 ; \mathrm{AlCl}_{3}$. $6 \mathrm{H}_{2} \mathrm{O}, 0.15 ; \mathrm{Na}_{2} \mathrm{Se}_{2} \mathrm{O}_{3}, 0.01 ; \mathrm{MnSO}_{4} . \mathrm{H}_{2} \mathrm{O}, 2.0 ; \mathrm{CoCl}_{2} .6 \mathrm{H}_{2} \mathrm{O}, 1.0$

${ }^{3}$ Vitamin premix ( $\mathrm{g} \mathrm{kg}^{-1}$ of mixture): L-ascorbic acid, 121.2; DL-a tocopheryl acetate, 18.8; thiamin hydrochloride, 2.7; riboflavin, 9.1; pyridoxine hydrochloride, 1.8; niacin, 36.4; Ca- -pantothenate, 12.7; myo-inositol, 181.8; D-biotin, 0.27; folic acid, 0.68; p-aminobezoic acid, 18.2; menadione, 1.8; retinyl acetate, 0.73; cholecalficerol, 0.003; cyanocobalamin, 0.003

${ }^{4}$ Di-calcium phosphate 
syringes to separate serum for the analysis of innate immune parameters. The blood samples were allowed to clot at room temperature for $30 \mathrm{~min}$ and centrifuged for $10 \mathrm{~min}$ at $5000 \times \mathrm{g}$. Then, the serum was separated and stored at $-80^{\circ} \mathrm{C}$. All the fish were starved $24 \mathrm{~h}$ prior to weighing or blood sampling.

Moisture and ash contents were analyzed according to AOAC (1995). Crude lipid was determined according to Folch et al. (1957) and crude protein was analyzed by an automatic Kjeltec Analyzer Unit 2300 (FOSS, Sweden). Microhematocrit technique was used to determine hematocrit (Brown 1980). An automated blood analyzer (SLIM, SEAC Inc., Florence, Italy) was used to measure hemoglobin and plasma levels of glucose and cholesterol. The oxidative radical generation by phagocytes during respiratory burst was estimated through NBT test by Anderson and Siwicki (1995). Plasma immunoglobulin (Ig) levels were measured by Siwicki and Anderson (1993). A turbidometric method was used to measure the level of serum lysozyme (Hultmark et al. 1980) with a slight adjustment. The method described by Quade and Roth (1997) was used to measure serum myeloperoxidase (MPO) activity. Serum superoxide dismutase (SOD) activity was estimated utilizing a SOD Assay Kit (Sigma, 19160). The serum anti-protease activity was estimated by Ellis (1990) with slight alterations (Magnadóttir et al. 1999). Glutathione peroxidase (GPx) and catalase activities were assayed using kits (Biovision, Inc. California, USA).

\section{Expression levels of liver IGF-I mRNA}

Liver samples were taken from three fish per tank and frozen immediately in liquid nitrogen. Total RNA isolation and gene expression determination were conducted according to Kim et al. 2017). The $18 \mathrm{~S}$ rRNA gene was used as the housekeeping gene. Primers were designed using the cloned sequence for both IGF-1 and 18S rRNA gene (NCBI Genbank accession no: AY996779 and AB259837). The relative expression ratio was calculated according to the mathematical model explained by Pfaffl (Pfaffl 2001): Ratio $=[($ EIGF-I) $\Delta$ GF (control-sample) $] /$ [(Eactin) Ct (control-sample)].

\section{Statistical analysis}

One-way analysis of variance (ANOVA) was performed to identify statistical differences among the dietary treatments using SPSS version 19.0 (SPSS Inc., Chicago, IL, USA). When differences were identified by ANOVA, Tukey's HSD multiple test was applied $(p<0.05)$. Data were presented as mean \pm SD.

\section{Results}

Growth performance and feed utilization of red seabream were significantly influenced by the dietary taurine supplementation in each FM replacement (Table 2). Final body weight (FBW) and weight gain (WG) of fish was significantly improved by dietary taurine supplementation to SM diets. Interestingly, SM20-T and SM35-T diets increased FBW and WG of fish to restore the HFM effects. Feed intake (FI), feed conversion ratio (FCR), and protein efficiency ratio (PER) of the fish fed taurine-supplemented diets were higher than those of their respective SM diets. The HFM effects were restored in fish fed SM20-T and SM35-T diets. However, reduced growth and feed utilization of red seabreams fed SM50 diet were not restored by taurine supplementation. Survival of fish was not affected by FM replacement or taurine supplementation. Hematological and biochemical parameters of red seabream were not significantly affected by dietary taurine or FM replacement (Table 3).

Table 2 Growth performance and feed utilization of red sea bream fed the eight experimental diets for 20 weeks

\begin{tabular}{|c|c|c|c|c|c|c|}
\hline & FBW $(g)^{1}$ & $W G(\%)^{2}$ & $\mathrm{Fl}^{3}$ & $\mathrm{FCR}^{4}$ & $\mathrm{PER}^{5}$ & Survival (\%) \\
\hline$\overline{\mathrm{HFM}}$ & $185 \pm 7.4^{\mathrm{ab}}$ & $77.6 \pm 5.6^{b c}$ & $77.6 \pm 1.8^{\mathrm{ab}}$ & $1.16 \pm 0.03^{b c}$ & $1.79 \pm 0.04^{\mathrm{ab}}$ & $91.7 \pm 2.9$ \\
\hline HFM-T & $192 \pm 2.9^{a}$ & $92.0 \pm 2.9^{\mathrm{a}}$ & $83.8 \pm 0.9^{a}$ & $1.05 \pm 0.04^{c}$ & $1.99 \pm 0.07^{\mathrm{a}}$ & $96.7 \pm 2.9$ \\
\hline SM20 & $170 \pm 5.0^{\text {cde }}$ & $69.5 \pm 5.0^{\mathrm{bcd}}$ & $71.4 \pm 4.7^{\mathrm{abc}}$ & $1.39 \pm 0.25^{\mathrm{abc}}$ & $1.53 \pm 0.29^{a b c}$ & $91.7 \pm 5.8$ \\
\hline SM20-T & $182 \pm 5.1^{\mathrm{abc}}$ & $82.2 \pm 5.1^{\mathrm{ab}}$ & $75.3 \pm 3.7^{\mathrm{abc}}$ & $1.06 \pm 0.02^{b c}$ & $1.96 \pm 0.04^{\mathrm{a}}$ & $96.7 \pm 2.9$ \\
\hline SM35 & $165 \pm 1.1^{\mathrm{de}}$ & $64.8 \pm 1.1^{\mathrm{cd}}$ & $66.5 \pm 4.1^{\mathrm{bc}}$ & $1.25 \pm 0.15^{\mathrm{abc}}$ & $1.68 \pm 0.18^{\mathrm{abc}}$ & $96.7 \pm 5.8$ \\
\hline SM35-T & $178 \pm 4.0^{\mathrm{bcd}}$ & $78.1 \pm 4.0^{b}$ & $73.6 \pm 9.8^{\mathrm{abc}}$ & $1.14 \pm 0.04^{b c}$ & $1.82 \pm 0.07^{\mathrm{ab}}$ & $96.7 \pm 5.8$ \\
\hline SM50 & $157 \pm 7.1^{e}$ & $56.7 \pm 7.1^{d}$ & $62.6 \pm 3.3^{c}$ & $1.62 \pm 0.07^{a}$ & $1.29 \pm 0.06^{c}$ & $95.0 \pm 5.0$ \\
\hline SM50-T & $171 \pm 2.7^{\mathrm{cd}}$ & $70.8 \pm 2.7^{\text {de }}$ & $65.4 \pm 1.3^{b c}$ & $1.46 \pm 0.27^{\mathrm{bc}}$ & $1.46 \pm 0.30^{b c}$ & $88.3 \pm 7.6$ \\
\hline
\end{tabular}

Values are mean of triplicate groups and presented as mean \pm SD. Values with different superscripts in the same column are significantly different $(p<0.05)$. The lack of superscript letter indicates no significant differences among treatments

${ }^{1}$ Final body weight

${ }^{2}$ Weight gain $=[($ final body weight - initial body weight $) /$ initial body weight $] \times 100$

${ }^{3}$ Feed intake $(\mathrm{g} / \mathrm{fish})=$ dry feed consumed $(\mathrm{g}) /$ fish

${ }^{4}$ Feed conversion ratio $=$ dry feed fed/wet weight gain

${ }^{5}$ Protein efficiency ratio $=$ fish weight gain $(\mathrm{g}) /$ protein 
Table 3 Hematological parameters of red sea bream fed the eight experimental diets for 20 weeks

\begin{tabular}{lllll}
\hline & $\begin{array}{l}\text { Hematocrit } \\
(\%)\end{array}$ & $\begin{array}{l}\text { Hemoglobin } \\
\left(\mathrm{g} \mathrm{dL}^{-1}\right)\end{array}$ & $\begin{array}{l}\text { Glucose } \\
\left(\mathrm{mg} \mathrm{dL}^{-1}\right)\end{array}$ & $\begin{array}{l}\text { Cholesterol } \\
\left(\mathrm{mg} \mathrm{dL}^{-1}\right)\end{array}$ \\
\hline HFM & $42.8 \pm 3.56$ & $6.47 \pm 0.59$ & $40.6 \pm 2.9$ & $211 \pm 24$ \\
HFM-T & $40.1 \pm 0.84$ & $6.01 \pm 0.62$ & $40.1 \pm 1.4$ & $215 \pm 13$ \\
SM20 & $41.0 \pm 1.86$ & $5.89 \pm 1.51$ & $40.9 \pm 3.7$ & $210 \pm 8$ \\
SM20-T & $39.6 \pm 8.55$ & $6.24 \pm 0.77$ & $40.3 \pm 2.4$ & $212 \pm 13$ \\
SM35 & $39.3 \pm 7.23$ & $6.11 \pm 0.89$ & $40.6 \pm 2.6$ & $224 \pm 8$ \\
SM35-T & $43.8 \pm 2.68$ & $6.01 \pm 0.76$ & $42.0 \pm 1.4$ & $217 \pm 18$ \\
SM50 & $38.4 \pm 2.36$ & $6.29 \pm 0.99$ & $41.1 \pm 4.6$ & $215 \pm 19$ \\
SM50-T & $40.7 \pm 5.13$ & $6.36 \pm 0.35$ & $39.6 \pm 2.2$ & $219 \pm 14$ \\
\hline
\end{tabular}

Values are mean of triplicate groups and presented as mean \pm SD

In the results of innate immune parameters (Table 4), the supplemental effect of taurine was not significant in each respective diet. However, dietary taurine supplementation in each FM replaced groups numerically increased the innate immunity of the fish. For the anti-protease activity, fish fed SM50 and SM50-T only showed significantly lower value than fish fed HFM diet. In GPx activity, SM50 group only exhibited significantly lower value than fish fed HFM diet, while SM50-T group did not significantly differ from the HFM group. Lysozyme and SOD activities were significantly decreased in fish fed SM35, SM50, and SM50-T diets compared to those of fish fed HFM diet. In MPO activity, no significant difference was found between HFM and other dietary groups. Whole body proximate composition and biometric parameters (Table 5) of red seabream were not significantly different after 20 weeks of the feeding trial.

The relative expression level of hepatic IGF-1 mRNA is shown in Fig. 1. Compared to HFM group, expression level was significantly higher in fish fed HFM-T and SM20-T diets. Expression level was reduced with the increase of SM levels in the diets. However, improved IGF-1 was observed in fish fed taurine-supplemented diets compared to their respective SM diets.

\section{Discussion}

Growth performance and feed utilization of red seabream were improved by supplementing taurine in FM replacement diets with plant protein source. Reduced growth and feed utilization were observed in fish fed SM diets. However, SM diets supplemented with $1 \%$ taurine enhanced the growth of fish compared to their respective SM diets. Taurine is known as a feed attractant for fishes. FI of fish can be enhanced by dietary taurine supplementation (Nguyen et al. 2015; Martins et al. 2018; Wei et al. 2019). In the present study, FI of red seabream fed taurine-supplemented diets was higher than that of their respective SM diets. Therefore, it suggests that taurine-added feeds are more attractable to red seabream compared to non-supplemented SM diets and its feed palatability can be improved by taurine. Similarly, we observed that the palatability of parrot fish diet was enhanced by taurine supplementation (Lim et al. 2013). It is well known that low FI leads to reduced growth performance and feed utilization of fish as shown in the present study. The positive growth effect of FM was restored in SM20 or SM35 diets by 1\% taurine supplementation. On the contrary, Biswas et al. (2007) observed that red seabream diet containing 30\% SM (40\% FM) without taurine was not capable to restore fish growth compared to a HFM diet (65\% FM). However, in line with our study, Takagi et al. (2006) found that HFM effects can be restored in red seabream by feeding a taurine added LFM diet. HFM effects were restored in

Table 4 Non-specific immune response of red sea bream fed the eight experimental diets for 20 weeks

\begin{tabular}{|c|c|c|c|c|c|c|c|}
\hline & $A P^{1}$ & $G P x^{2}$ & Lysozyme $^{3}$ & $\mathrm{MPO}^{4}$ & $\mathrm{NBT}^{5}$ & $\mathrm{SOD}^{6}$ & $\lg ^{7}$ \\
\hline$\overline{H F M}$ & $19.5 \pm 1.17^{a b}$ & $95.2 \pm 8.23^{a b}$ & $5.4 \pm 0.10^{a}$ & $1.45 \pm 0.05^{a b}$ & $0.93 \pm 0.08$ & $67.5 \pm 0.5^{a b}$ & $21.1 \pm 0.39$ \\
\hline HFM-T & $20.5 \pm 3.19^{a}$ & $99.2 \pm 4.40^{a}$ & $5.6 \pm 0.24^{a}$ & $1.49 \pm 0.07^{a}$ & $0.91 \pm 0.09$ & $70.2 \pm 0.8^{a}$ & $20.2 \pm 0.57$ \\
\hline SM20 & $18.8 \pm 0.07^{a b c}$ & $85.8 \pm 2.43^{b c}$ & $4.6 \pm 0.25^{a b}$ & $1.36 \pm 0.06^{a b}$ & $0.95 \pm 0.09$ & $64.4 \pm 1.5^{\mathrm{bc}}$ & $20.2 \pm 0.40$ \\
\hline SM20-T & $19.7 \pm 0.30^{a b c}$ & $92.2 \pm 1.71^{\mathrm{abc}}$ & $5.1 \pm 0.22^{a b}$ & $1.42 \pm 0.20^{a b}$ & $0.91 \pm 0.17$ & $67.2 \pm 1.9^{a b}$ & $21.6 \pm 0.83$ \\
\hline SM35 & $17.1 \pm 1.23^{\mathrm{bcd}}$ & $82.5 \pm 3.47^{b c}$ & $4.7 \pm 0.10^{b}$ & $1.31 \pm 0.05^{b}$ & $0.88 \pm 0.07$ & $62.6 \pm 0.6^{\mathrm{cd}}$ & $19.9 \pm 2.00$ \\
\hline SM35-T & $19.6 \pm 0.79^{a b c}$ & $87.6 \pm 0.76^{b c}$ & $5.0 \pm 0.08^{a b}$ & $1.37 \pm 0.03^{a b}$ & $0.94 \pm 0.01$ & $64.6 \pm 1.6^{b c}$ & $21.3 \pm 1.57$ \\
\hline SM50 & $15.4 \pm 1.68^{d}$ & $81.0 \pm 2.29^{c}$ & $4.2 \pm 0.48^{b}$ & $1.29 \pm 0.05^{b}$ & $0.98 \pm 0.05$ & $59.6 \pm 0.8^{d}$ & $19.8 \pm 2.15$ \\
\hline SM50-T & $16.7 \pm 1.56^{\mathrm{cd}}$ & $84.0 \pm 3.39^{b c}$ & $4.7 \pm 0.09^{b}$ & $1.32 \pm 0.02^{b}$ & $0.90 \pm 0.19$ & $60.6 \pm 1.8^{d}$ & $21.3 \pm 0.29$ \\
\hline
\end{tabular}

Values are mean of triplicate groups and presented as mean \pm SD. Values in the same column having different superscript letters are significantly different $(p<$ 0.05). The lack of superscript letter indicates no significant differences among treatments

${ }^{1}$ Antiprotease (\% inhibition)

${ }^{2}$ Glutathione peroxidase activity $\left(\mathrm{mU} \mathrm{ml}^{-1}\right)$

${ }^{3}$ Lysozyme activity $\left(\mu \mathrm{g} \mathrm{mL}^{-1}\right.$ )

${ }^{4}$ Myeloperoxidase level

${ }^{5}$ Nitro blue tetrazolium activity

${ }^{6}$ Superoxide dismutase (\% inhibition)

${ }^{7}$ Total immunoglobulin $\left(\mathrm{mg} \mathrm{mL}^{-1}\right.$ ) 
Table 5 Whole body proximate composition (wet basis) and biometric parameters of red sea bream fed the eight experimental diets for 20 weeks

\begin{tabular}{llllllll}
\hline & Dry matter (\%) & Protein (\%) & Lipid (\%) & Ash (\%) & CF $^{1}$ & HSI $^{2}$ & VSI $^{3}$ \\
\hline HFM & $36.1 \pm 1.9$ & $17.4 \pm 0.2$ & $12.1 \pm 1.9$ & $4.3 \pm 0.53$ & $2.11 \pm 0.24$ & $0.95 \pm 0.23$ & $5.61 \pm 0.25$ \\
HFM-T & $37.5 \pm 2.4$ & $18.3 \pm 0.7$ & $10.2 \pm 0.3$ & $4.0 \pm 0.49$ & $1.97 \pm 0.13$ & $0.90 \pm 0.07$ & $5.58 \pm 0.56$ \\
SM20 & $35.8 \pm 0.9$ & $16.1 \pm 1.5$ & $10.1 \pm 1.5$ & $4.7 \pm 0.97$ & $2.06 \pm 0.19$ & $1.17 \pm 0.42$ & $6.28 \pm 0.11$ \\
SM20-T & $36.0 \pm 3.3$ & $15.8 \pm 2.2$ & $11.7 \pm 0.8$ & $4.2 \pm 0.46$ & $2.10 \pm 0.11$ & $1.00 \pm 0.14$ & $5.88 \pm 0.55$ \\
SM35 & $37.2 \pm 0.5$ & $18.4 \pm 0.5$ & $11.9 \pm 1.8$ & $4.3 \pm 0.92$ & $2.06 \pm 0.12$ & $0.94 \pm 0.10$ & $5.91 \pm 0.23$ \\
SM35-T & $38.7 \pm 2.9$ & $19.3 \pm 0.5$ & $10.6 \pm 1.5$ & $4.3 \pm 0.43$ & $2.17 \pm 0.22$ & $1.03 \pm 0.22$ & $5.53 \pm 0.37$ \\
SM50 & $36.0 \pm 0.4$ & $18.1 \pm 0.6$ & $11.1 \pm 0.5$ & $3.8 \pm 0.47$ & $2.12 \pm 0.08$ & $0.92 \pm 0.04$ & $5.25 \pm 0.68$ \\
SM50-T & $38.6 \pm 1.8$ & $17.1 \pm 2.3$ & $11.3 \pm 0.3$ & $4.2 \pm 0.15$ & $1.95 \pm 0.15$ & $0.85 \pm 0.07$ & $5.25 \pm 0.05$ \\
\hline
\end{tabular}

Values are mean of triplicate groups and presented as mean \pm SD

${ }^{1}$ Conditional factor $=\left(\right.$ Fish weight/Fish length $\left.{ }^{3}\right) \times 100$

${ }^{2}$ Hepatosomatic index $=($ Liver weight/Fish weight $) \times 100$

${ }^{3}$ Viscerosomatic index $=($ Viscera weight/Fish weight $) \times 100$

common dentex (Dentex dentex) by feeding a LFM diet in which $40 \%$ FM was replaced by SM with taurine supplementation (Chatzifotis et al. 2008). In our previous study, we observed that 30\% FM was successfully replaced with SM in diet for parrot fish with $1 \%$ taurine (Lim et al. 2013). Therefore, it can be assumed that growth performance of red seabream which is negatively affected by SM can be restored or compensated by taurine supplementation to the diets containing high proportion of plant protein ingredients as FM substitutes.

Taurine can stimulate the secretion of connective tissue growth factor (CTGF) in a dose-dependent manner (Yuan et al. 2007). CTGF is rich in cysteine, mitogen, fibroblast, and angiogenic factors involved in development and regulation of tissue growth (Bradham et al. 1991; Wang et al. 2015). Therefore, taurine-supplemented diets might exhibit the ability to compensate growth of fish fed SM diets. In addition, SM contains anti-nutritional factors such as glycinin, $\beta$-conglycinin, tannin, phytic acid, saponins, and trypsin inhibitors (Francis et al. 2001). As a result of these anti-nutritional factors, growth of fishes can be reduced when they were fed diets having a high level of SM (Wilson and Poe 1985; Wang et al. 2016; Nguyen et al. 2017). Dietary SM supplementation was known to downregulate the synthesis of bile acid and enterohepatic circulation of rainbow trout (Oncorhynchus mykiss) (Murashita et al. 2018). However, Yu et al. (2013) observed that growth inhibitory effects of SM can be compensated by taurine, lysine, and methionine supplementation for juvenile obscure puffer (Takifugu obscurus). In the present study, similarly, taurine supplementation seemed to compensate the growth inhibitory effect induced by SM in red seabream.

In teleost fish, innate immunity is the most important defense mechanism against bacterial infections. Innate immune parameters of red seabream were significantly improved by the dietary taurine supplementation in the present study. However, dietary SM supplementation for

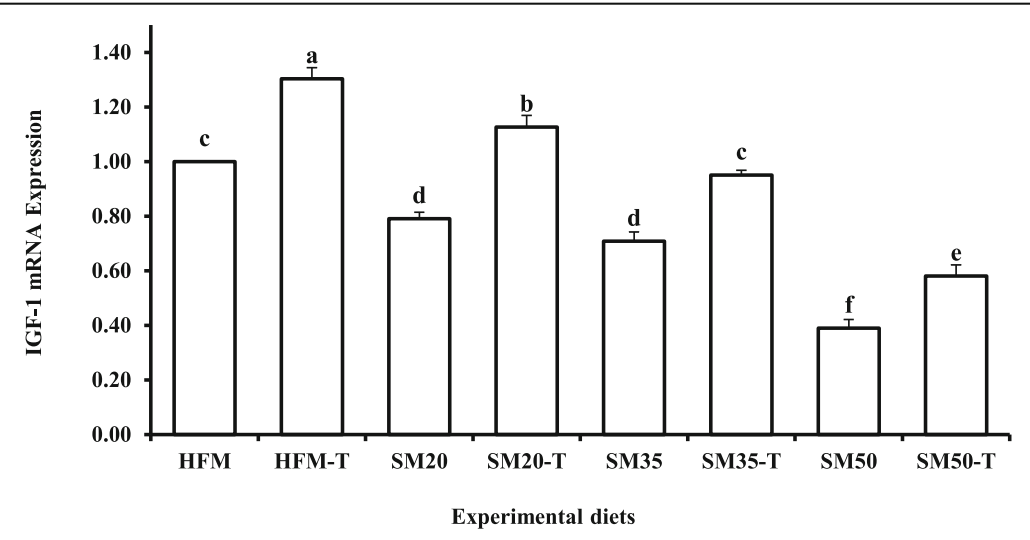

Fig. 1 Liver insulin-like growth factors I (IGF-I) mRNA expression of red seabream for each diet group expressed as a ratio to control diet values. Data are presented as mean \pm SD from three replicate tanks. Different letters above the bars denote significant differences between diet groups at the $p<0.05$ level 
FM replacement caused reduced performance of the innate immune response. Taurine exerts ability to enhance immunity of fish and shellfish. For instance, innate immune responses of olive flounder were enhanced in fish by $0.25-1.0 \%$ taurine supplementation in a FM diet (Kim et al. 2017). Dong et al. (2018) found that dietary supplementation of taurine is important to improve the innate immunity of Chinese mitten crab (Eriocheir sinensis). Immune parameters of yellow catfish (Pelteobagrus fulvidraco) were significantly enhanced by dietary taurine supplementation ( $\mathrm{Li}$ et al. 2016). Therefore, it is believed that the increased immunity of red seabream in the present study was due to the dietary taurine supplementation. There is no report about the exact mechanisms by which taurine improve the immunity of fish. However, it was reported that taurine can enhance the functions of leucocytes (Wang et al. 2009). Leucocytes are the site for immune functions such as phagocytosis and respiratory burst. Mühling et al. (2002) observed that the generation of superoxide anion and hydrogen peroxide was decreased in human leucocytes that were incubated with taurine. On the other way, radical scavenging activity was increased after incubation with taurine. The study suggested that extracellular and intracellular taurine might act as an antioxidant to improve immune function. Accordingly, in our case, the increased SOD and MPO activities in red seabream might be attributed to the reduction of superoxide and peroxide anion by taurine supplementation in its diet indicating that the immunity of the fish fed SM diets without taurine was decreased. Previous reports elucidated that immune responses of fish can be reduced with the increase of SM level in their diets (Burrells et al. 1999; Buentello et al. 2010; Deng et al. 2013). Bakke-McKellep et al. (2000) observed a decreased immunoglobulin M level in Atlantic salmon (Salmo salar) following a SM diet feeding. Also, dietary SM increased the susceptibility of Atlantic salmon to furunculosis (Krogdahl et al. 2000) and mortality of channel catfish (Ictalurus punctatus) after a challenge against Edwardsiella ictaluri (Peres et al. 2003) as a result of reduced immunity. However, in our case, reduced immunity of red seabream fed SM diets up to $35 \%$ FM replacement was successfully recovered by $1 \%$ taurine incorporation to their respective SM diets.

In the present study, an improved expression level of IGF-1 mRNA was observed in fish fed taurinesupplemented diets compared to the respective SM diets. In a previous study, we observed that IGF-1 mRNA expression of olive flounder can be enhanced by dietary taurine supplementation (Kim et al. 2017). IGF1 , also known as somatomedin $\mathrm{C}$, is an endocrine hormone which is produced in liver to mediate prenatal and postnatal growth of vertebrates (Coleman and Tsongalis
2010). IGF-1 production in fishes is stimulated by growth hormone $(\mathrm{GH})$ and modulated by nutritional status (Beckman 2011). Expression of IGF-1 in fish can be downregulated by feeding a high-plant protein diet (Gaylord et al. 2007; Espe et al. 2016). Gaylord et al. (2007) observed upregulated IGF-1 expression in rainbow trout plasma when the fish was fed a taurinesupplementedall-plant protein diet. Exact mechanism for the upregulation of IGF-1 by taurine is unclear in fishes. However, GH secretion of animals was induced by taurine in previous studies (Collu et al. 1978; Ikuyama et al. 1988; Huxtable 1992; Moon et al. 2015). Also, production of IGF-1 in gilthead sea bream (Sparus aurata) was enhanced by GH administration (Pérez-Sánchez et al. 1994). Therefore, secretion of IGF-1 might be stimulated by $\mathrm{GH}$ in fishes. Increased $\mathrm{GH}$ secretion by dietary taurine supplementation might be a reason to the increased expression levels of liver IGF-1 in the present study. Moreover, Pérez-Sánchez et al. (1994) observed that hepatic IGF-1 level in gilthead sea bream was increased with the increase of feed consumption. Accordingly, FI of red seabream was increased by $1 \%$ taurine supplementation to SM diets in the present study and IGF-1 level was significantly increased with the FI.

Biochemical and biometric parameters of red seabream were not significantly affected by FM replacement with SM or taurine supplementation. In the previous studies, plasma total protein, total cholesterol, triglyceride levels, and HSI of red seabream were significantly reduced when fish were fed taurine-incorporated LFM diet in which $70 \%$ of FM was replaced with SM (Goto et al. 2001). Kim et al. (2017) observed that hematocrit and hemoglobin level of olive flounder were significantly enhanced by taurine supplementation to their diets. It seems that there is a discrepancy among biochemical and biometric results obtained from different studies on dietary taurine supplementations.

\section{Conclusions}

The results proved that taurine exhibits ability to alleviate negative effects caused by SM on growth performance, feed utilization, innate immunity, and IGF-1 mRNA expression of red seabream at low water temperature. Also, the optimum replacement level of FM with SM might be $35 \%$ in red seabream diet with $1 \%$ taurine supplementation. These findings will help understand the role of taurine in fishes when dietary FM is replaced with plant protein sources in a high level.

\section{Abbreviations}

ANOVA: One-way analysis of variance; FCR: Feed conversion ratio; Fl: Feed intake; FM: Fishmeal; GPx: Glutathione peroxidase; HFM: High fishmeal; Ig: Immunoglobulin; IGF-1: Insulin-like growth factor 1; LFM: Low fishmeal; MPO: Myeloperoxidase; mRNA: Messenger ribonucleic acid; NBT: Nitro blue 
tetrazolium; PER: Protein efficiency ratio; SGR: Specific growth rate; SM: Soybean meal; SOD: Superoxide dismutase; T: Taurine; WG: Weight gain

\section{Acknowledgements}

This research was supported by Basic Science Research Program through the National Research Foundation of Korea (NRF) funded by the Ministry of Education (2019R1A6A1A03033553).

\section{Authors' contributions}

GLBEG conducted the feeding trial, analysis, and manuscript preparation. $\mathrm{CL}_{\text {, }}$ JHS, and MGK participated in the sample collection and analyses. KJ and BJL organized, designed, and completed the manuscript. All authors have read and approved the final manuscript.

\section{Availability of data and materials}

All datasets analyzed in this study are available from the corresponding author on reasonable request.

\section{Ethics approval and consent to participate}

Experimental protocols followed the guidelines of the Animal Care and Use Committee of Jeju National University.

\section{Competing interests}

The authors declare that they have no competing interests.

\section{Author details}

${ }^{1}$ Department of Marine Life Sciences, Jeju National University, Jeju 63243, South Korea. ${ }^{2}$ Aquafeed Research Center, National Institute of Fisheries Science, Pohang 37517, South Korea. ${ }^{3}$ Marine Science Institute, Jeju National University, Jeju, Self-Governing Province 63333, South Korea.

\section{Received: 1 August 2019 Accepted: 25 September 2019}

\section{Published online: 30 October 2019}

\section{References}

Anderson DP, Siwicki AK. Basic hematology and serology for fish health programs. In: Diseases in Asian Aquaculture II (ed. by M. Shariff, J.R. Arthur \& R.P. Subasinghe), Fish Health Section, Asian Fisheries Society, Manila: Leetown Science Center; 1995. p. 185-202.

Antonopoulou E, Chouri E, Feidantsis K, Lazou A, Chatzifotis S. Effects of partial dietary supplementation of fish meal with soymeal on the stress and apoptosis response in the digestive system of common dentex (Dentex dentex). J Biol Res. 2017:24:14. https://doi.org/10.1186/s40709-017-0071-1.

AOAC. Official methods of analysis. 16th edition. Arlington: Association of Official Analytical Chemists; 1995

Bakke-McKellep AM, Press CM, Baeverfjord G, Krogdahl A, Landsverk T. Changes in immune and enzyme histochemical phenotypes of cells in the intestinal mucosa of Atlantic salmon, Salmo salar L., with soybean meal-induced enteritis. J Fish Dis. 2000;23:115-27. https://doi.org/10.1046/j.1365-2761.2000. 00218.x.

Beckman BR. Perspectives on concordant and discordant relations between insulin-like growth factor 1 (IGF1) and growth in fishes. Gen Comp Endocrinol. 2011;170:233-52. https://doi.org/10.1016/J.YGCEN.2010.08.009.

Biswas AK, Kaku H, Ji SC, Seoka M, Takii K. Use of soybean meal and phytase for partial replacement of fish meal in the diet of red sea bream, Pagrus major Aquaculture. 2007;267:284-91. https://doi.org/10.1016/J.AQUACULTURE.2007. 01.014

Bradham DM, Igarashi A, Potter RL, Grotendorst GR. Connective tissue growth factor: a cysteine-rich mitogen secreted by human vascular endothelial cells is related to the SRC-induced immediate early gene product CEF-10. J Cell Biol. 1991;114:1285-94. https://doi.org/10.1083/jcb.114.6.1285.

Brett JR. Energetic responses of salmon to temperature. A study of some thermal relations in the physiology and freshwater ecology of sockeye salmon (Oncorhynchus nerkd). Amer Zool. 1971;11:99-113.

Brosnan JT, Brosnan ME. The sulfur-containing amino acids: an overview. J Nutr. 2006;136:1636S-40S.

Brown BA. Routine hematology procedures. In: Brown BA, editor. Hematology, principles and procedures. Philadelphia: Lea and Febiger; 1980. p. 71-112.

Buentello JA, Neill WH, Gatlin DM. Effects of dietary prebiotics on the growth, feed efficiency and non-specific immunity of juvenile red drum Sciaenops ocellatus fed soybean-based diets. Aquac Res. 2010;41:411-8. https://doi.org/ 10.1111/j.1365-2109.2009.02178.x.

Burrells C, Williams PD, Southgate PJ, Crampton VO. Immunological, physiological and pathological responses of rainbow trout (Oncorhynchus mykiss) to increasing dietary concentrations of soybean proteins. Vet Immunol Immunopathol. 1999;72:277-88. https://doi.org/10.1016/S01652427(99)00143-9.

Chatzifotis S, Polemitou I, Divanach P, Antonopoulou E. Effect of dietary taurine supplementation on growth performance and bile salt activated lipase activity of common dentex, Dentex dentex, fed a fish meal/soy protein concentrate-based diet. Aquaculture. 2008;275:201-8. https://doi.org/10.1016/ j.aquaculture.2007.12.013

Chen JN, Takeuchi T, Takahashi T, Tomoda T, Koiso M, Kuwada H. Effect of rotifers enriched with taurine on growth and survival activity of red sea bream Pagrus major larvae. Nippon Suisan Gakkaishi. 2005;70:542-7. https://doi.org/ 10.2331/suisan.70.542

Coleman WB, Tsongalis GJ, editors. Essential concepts in molecular pathology: Academic Press; 2010

Collu R, Charpenet G, Clermont MJ. Antagonism by taurine of morphine induced growth hormone secretion. Can J Neurol Sci J Can des Sci Neurol. 1978;5: 139-42. https://doi.org/10.1017/S0317167100024938.

Deng J, Kang B, Tao L, Rong H, Zhang X. Effects of dietary cholesterol on antioxidant capacity, non-specific immune response, and resistance to Aeromonas hydrophila in rainbow trout (Oncorhynchus mykiss) fed soybean meal-based diets. Fish Shellfish Immunol. 2013;34:324-31. https://doi.org/10. 1016/j.fsi.2012.11.008

Dong J, Cheng R, Yang Y, Zhao Y, Wu G, Zhang R, et al. Effects of dietary taurine on growth, non-specific immunity, anti-oxidative properties and gut immunity in the Chinese mitten crab Eriocheir sinensis. Fish Shellfish Immunol. 2018:82:212-9. https://doi.org/10.1016/j.fsi.2018.08.029.

Ellis AE. Serum antiproteases in fish. In: Stolen JS, Fletcher TC, Anderson DP, Roberson BS, editors. Techniques in fish immunology. NJ: SOS Publications; 1990. p. 95-9.

El-Sayed AFM. Is dietary taurine supplementation beneficial for farmed fish and shrimp? A comprehensive review. Rev Aquac. 2014;6:241-55. https://doi.org/ 10.1111/raq.12042.

Espe M, Veiseth-Kent E, Zerrahn JE, Rønnestad I, Aksnes A. Juvenile Atlantic salmon decrease white trunk muscle IGF-1 expression and reduce muscle and plasma free Sulphur amino acids when methionine availability is low while liver Sulphur metabolites mostly is unaffected by treatment. Aquac Nutr. 2016;22:801-12. https://doi.org/10.1111/anu.12294.

Folch J, Lees M, Stanley GS. A simple method for the isolation and purification of total lipides from animal tissues. J Biol Chem. 1957;226:497-509.

Francis G, Makkar HP, Becker K. Antinutritional factors present in plant-derived alternate fish feed ingredients and their effects in fish. Aquaculture. 2001;199: 197-227.

Gaylord TG, Barrows FT, Teague AM, Johansen KA, Overturf KE, Shepherd B. Supplementation of taurine and methionine to all-plant protein diets for rainbow trout (Oncorhynchus mykiss). Aquaculture. 2007;269:514-24.

Goto T, Takagi S, Ichiki T, Sakai T, Endo M, Yoshida T, et al. Studies on the green liver in cultured red sea bream fed low level and non-fish meal diets: relationship between hepatic taurine and biliverdin levels. Fish Sci. 2001;67: 58-63. https://doi.org/10.1046/j.1444-2906.2001.00199.x.

Goto T, Ui T, Une M, Kuramoto T, Kihira K, Hoshita T. Bile salt composition and distribution of the D-cysteinolic acid conjugated bile salts in fish. Fish Sci. 1996;62:606-9.

Goto T, Ui T, Une M, Kuramoto T, Kihira K, Hoshita T. Bile salt composition and distribution of the D-cysteinolic acid conjugated bile salts in fish. Fish Sci. 2017;62:606-9. https://doi.org/10.2331/fishsci.62.606.

Hano T, Ito K, Kono K, Ito M, Ohkubo N, Mochida K. Effect of taurine supplementation on hepatic metabolism and alleviation of cadmium toxicity and bioaccumulation in a marine teleost, red sea bream, Pagrus major. Fish Physiol Biochem. 2017a:43:137-52

Hano T, Ito M, Ito K, Kono K, Ohkubo N. Dietary taurine supplementation ameliorates the lethal effect of phenanthrene but not the bioaccumulation in a marine teleost, red sea bream, Pagrus major. Ecotoxicol Environ Saf. 2017b;137:272-80. https://doi.org/10.1016/j.ecoenv.2016.12.005.

Hernandez MD, Martinez FJ, Jover M, Garcia GB. Effects of partial replacement of fish meal by soybean meal in sharpsnout seabream (Diplodus puntazzo) diet. Aquaculture. 2007;263:159-67.

Hien TT, Be TT, Lee CM, Bengtson DA. Development of formulated diets for snakehead (Channa striata and Channa micropeltes): can phytase and taurine 
supplementation increase use of soybean meal to replace fish meal? Aquaculture. 2015;448:334-40. https://doi.org/10.1016/j.aquaculture.2015.06.020.

Hultmark D, Steiner H, Rasmuson T, BOMAN HG. Insect immunity. Purification and properties of three inducible bactericidal proteins from hemolymph of immunized pupae of Hyalophora cecropia. Eur J Biochem. 1980;106:7-16. https://doi.org/10.1111/j.1432-1033.1980.tb05991.x.

Huxtable RJ. Physiological actions of taurine. Physiol Rev. 1992;72:101-63. https:// doi.org/10.1152/physrev.1992.72.1.101.

Ikuyama S, Okajima T, Ichi KK, Ibayashi H. Effect of taurine on growth hormone and prolactin secretion in rats: possible interaction with opioid peptidergic system. Life Sci. 1988;43:807-12. https://doi.org/10.1016/0024-3205(88)90506-1.

Jensen AJ, Forseth T, Johnsen BO. Latitudinal variation in growth of young brown trout Salmo trutta. J Anim Ecol. 2000;69:1010-20.

Kim JM, Malintha GHT, Gunathilaka GLBE, Lee C, Kim MG, Lee BJ, et al. Taurine supplementation in diet for olive flounder at low water temperature. Fish Aquat Sci. 2017;20:20. https://doi.org/10.1186/s41240-017-0065-9.

Kim SK, Matsunari H, Nomura K, Tanaka H, Yokoyama M, Murata Y, et al. Effect of dietary taurine and lipid contents on conjugated bile acid composition and growth performance of juvenile Japanese flounder Paralichthys olivaceus. Fish Sci. 2008;74:875-81. https://doi.org/10.1111/j.1444-2906.2008.01602.x.

Kim SK, Takeuchi T, Yokoyama M, Murata Y, Kaneniwa M, Sakakura Y. Effect of dietary taurine levels on growth and feeding behavior of juvenile Japanese flounder Paralichthys olivaceus. Aquaculture. 2005;250:765-74. https://doi.org/ 10.1016/j.aquaculture.2005.04.073.

Kim YS, Sasaki T, Awa M, Inomata M, Honryo T, Agawa Y, et al. Effect of dietary taurine enhancement on growth and development in red sea bream Pagrus major larvae. Aquac Res. 2016;47:1168-79. https://doi.org/10.1111/are.12573.

Krogdahl Å, Bakke-Mckellep AM, RØed KH, Baeverfjord G. Feeding Atlantic salmon Salmo salar L. soybean products: effects on disease resistance (furunculosis), and lysozyme and IgM levels in the intestinal mucosa. Aquac Nutr. 2000;6: 77-84. https://doi.org/10.1046/j.1365-2095.2000.00129.x.

Kumar S, Sándor Zs J, Nagy Z, Fazekas G, Havasi M, Sinha AK, et al. Potential of processed animal protein versus soybean meal to replace fish meal in practical diets for European catfish (Silurus glanis): growth response and liver gene expression. Aquac Nutr. 2017;23:1179-89. https:/doi.org/10.1111/anu.12487.

Li M, Lai H, Li Q, Gong S, Wang R. Effects of dietary taurine on growth, immunity and hyperammonemia in juvenile yellow catfish Pelteobagrus fulvidraco fed all-plant protein diets. Aquaculture. 2016;450:349-55. https://doi.org/10.1016/ j.aquaculture.2015.08.013.

Lim C, Akiyama DM. Full-fat soybean meal utilization by fish. Asian Fish Sci. 1992; 5:181-97

Lim SJ, Lee KJ. Supplemental iron and phosphorus increase dietary inclusion of cottonseed and soybean meal in olive flounder (Paralichthys olivaceus). Aquac Nutr. 2008;14:423-30.

Lim SJ, Oh DH, Khosravi S, Cha JH, Park SH, Kim KW, et al. Taurine is an essential nutrient for juvenile parrot fish Oplegnathus fasciatus. Aquaculture. 2013;414415:274-9. https://doi.org/10.1016/j.aquaculture.2013.08.013.

Magnadóttir B, Jónsdóttir H, Helgason S, Björnsson B, Jørgensen TØ, Pilström L. Humoral immune parameters in Atlantic cod (Gadus morhua L.): I. the effects of environmental temperature. Comp Biochem Physiol B: Biochem Mol Biol. 1999;122:173-80. https://doi.org/10.1016/S0305-0491(98)10156-6.

Martinez JB, Chatzifotis S, Divanach P, Takeuchi T. Effect of dietary taurine supplementation on growth performance and feed selection of sea bass Dicentrarchus labrax fry fed with demand-feeders. Fish Sci. 2004;70:74-9.

Martins N, Estevão-Rodriques T, Diógenes AF, Diaz-Rosales P, Oliva-Teles A, Peres $\mathrm{H}$. Taurine requirement for growth and nitrogen accretion of European sea bass (Dicentrarchus labrax, L.) juveniles. Aquaculture. 2018;494:19-25. https:// doi.org/10.1016/j.aquaculture.2018.05.007

Matsunari $\mathrm{H}$, Hamada K, Mushiake K, Takeuchi T. Effects of taurine levels in broodstock diet on reproductive performance of yellowtail Seriola quinqueradiata. Fish Sci. 2006;72:955-60. https:/doi.org/10.1111/j.1444-2906.2006.01243.x.

Matsunari H, Yamamoto T, Kim SK, Goto T, Takeuchi T. Optimum dietary taurine level in casein-based diet for juvenile red sea bream Pagrus major. Fish Sci. 2008;74:347-53. https://doi.org/10.1111/j.1444-2906.2008.01532.x.

Moon PD, Kim MH, Lim HS, et al. Taurine, a major amino acid of oyster, enhances linear bone growth in a mouse model of protein malnutrition. BioFactors. 2015;41:190-7. https://doi.org/10.1002/biof.1213

Mühling J, Fuchs M, Fleck C, Sablotzki A, Krüll M, Dehne MG, et al. Effects of arginine, L-alanyl-L-glutamine or taurine on neutrophil (PMN) free amino acid profiles and immune functions in vitro. Amino Acids. 2002;22:39-53. https:// doi.org/10.1007/s726-002-8200-9.
Murashita K, Rønnestad I, Furuita H, Matsunari H, Oku H, Yamamoto T. Effects of dietary soybean meal on the bile physiology in rainbow trout, Oncorhynchus mykiss. Aquaculture. 2018;490:303-10. https://doi.org/10.1016/j.aquaculture.2018.02.047.

Nguyen HP, Khaoian P, Fukada H, Suzuki N, Masumoto T. Feeding fermented soybean meal diet supplemented with taurine to yellowtail Seriola quinqueradiata affects growth performance and lipid digestion. Aquac Res. 2015:46:1101-10. https://doi.org/10.1111/are.12267.

Nguyen HP, Khaoian P, Furutani T, Nagano J, Fukada H, Masumoto T. Effects of alcohol extract of defatted soybean meal on growth performance and digestive physiology of yellowtail Seriola quinqueradiata. Fish Sci. 2017:83:99106. https://doi.org/10.1007/s12562-016-1049-x.

Öz M. Effects of garlic (Allium sativum) supplemented fish diet on sensory, chemical and microbiological properties of rainbow trout during storage at18 C. LWT. 2018a;92:155-60. https://doi.org/10.1016/j.lwt.2018.02.030.

Öz M, Dikel S, Durmus M. Effect of black cumin oil (Nigella sativa) on the growth performance, body composition and fatty acid profile of rainbow trout (Oncorhynchus mykiss). Iran J Fish Sci. 2018b;17:713-24.

Öz M, Dikel S, Durmuş M, Özoğul Y. Effects of black cumin oil (Nigella sativa) on sensory, chemical and microbiological properties of rainbow trout during 23 days of storage at 2 \pm 1 C. J Aquat Food Prod Technol. 2017;26:665-74. https://doi.org/10.1080/10498850.2016.1253631.

Öz M, Inanan BE, Dikel S. Effect of boric acid in rainbow trout (Oncorhynchus mykiss) growth performance. J Appl Anim Res. 2018c;46:990-3. https://doi. org/10.1080/09712119.2018.1450258

Park GS, Takeuchi T, Yokoyama M, Seikai T. Optimal dietary taurine level for growth of juvenile Japanese flounder Paralichthys olivaceus. Fish Sci. 2002;68: 824-9. https://doi.org/10.1046/j.1444-2906.2002.00498.x.

Peres H, Lim C, Klesius PH. Nutritional value of heat-treated soybean meal for channel catfish (Ictalurus punctatus). Aquaculture. 2003;225:67-82. https://doi. org/10.1016/S0044-8486(03)00289-8.

Pérez-Sánchez J, Marti-Palanca H, Le Bail PY. Seasonal changes in circulating growth hormone $(\mathrm{GH})$, hepatic $\mathrm{GH}$-binding and plasma insulin-like growth factor-l immunoreactivity in a marine fish, gilthead sea bream, Sparus aurata. Fish Physiol Biochem. 1994;13:199-208. https://doi.org/10.1007/BF00004358.

Pfaffl MW. A new mathematical model for relative quantification in real-time RTPCR. Nucleic Acids Res. 2001;29:e45.

Quade MJ, Roth JA. A rapid, direct assay to measure degranulation of bovine neutrophil primary granules. Vet Immunol Immunopathol. 1997;58:239-48. https://doi.org/10.1016/S0165-2427(97)00048-2.

Salze GP, Davis DA. Taurine: a critical nutrient for future fish feeds. Aquaculture. 2015;437:215-29. https://doi.org/10.1016/j.aquaculture.2014.12.006.

Siwicki AK, Anderson DP. Nonspecific defense mechanisms assay in fish: II. Potential killing activity of neutrophils and macrophages, lysozyme activity in serum and organs and total immunoglobulin level in serum. Fish disease diagnosis and prevention. Methods. FAO-project GCP/INT/JPA, IFI Olsztyn, Poland; 1993. p. 105-12.

Takagi S, Murata H, Goto T, Endo M, Yamashita H, Ukawa M. Taurine is an essential nutrient for yellowtail Seriola quinqueradiata fed non-fish meal diets based on soy protein concentrate. Aquaculture. 2008:280:198-205. https:// doi.org/10.1016/j.aquaculture.2008.05.012.

Takagi S, Murata H, Goto T, Hatate H, Endo M, Yamashita H, et al. Necessity of dietary taurine supplementation for preventing green liver symptom and improving growth performance in yearling red sea bream Pagrus major fed nonfishmeal diets based on soy protein concentrate. Fish Sci. 2010;76:11930. https://doi.org/10.1007/s12562-009-0185-y.

Takagi S, Murata H, Goto T, Hatate H, Endo M, Yamashita $H$, et al. Role of taurine deficiency in inducing green liver symptom and effect of dietary taurine supplementation in improving growth in juvenile red sea bream Pagrus major fed non-fishmeal diets based on soy protein concentrate. Fish Sci. 2011;77:235-44. https://doi.org/10.1007/s12562-011-0322-2.

Takagi S, Murata H, Goto T, Ichiki T, Endo M, Hatate H. Efficacy of taurine supplementation for preventing green liver syndrome and improving growth performance in yearling red sea bream Pagrus major fed lowfishmeal diet. Fish Sci. 2006;72:1191-9. https://doi.org/10.1111/j.14442906.2006.01276.x

Takeuchi T, Park GS, Seikai T, Yokoyama M. Taurine content in Japanese flounder Paralichthys olivaceus T. \& S. and red sea bream Pagrus major T. \& S. during the period of seed production. Aquac Res. 2001;32:244-8. https://doi.org/10. 1046/j.1355-557x.2001.00021.x.

Titgemeyer EC, Merchen NR, Berger LL. Evaluation of soybean meal, corn gluten meal, blood meal and fish meal as sources of nitrogen and 
amino acids disappearing from the small intestine of steers. J Anim Sci. 1989:67:262-75.

Wang L, Zhao N, Zhang F, Yue W, Liang M. Effect of taurine on leucocyte function. Eur J Pharmacol. 2009;616:275-80. https://doi.org/10.1016/j.ejphar. 2009.05.027.

Wang L, Zhou H, He R, Xu W, Mai K, He G. Effects of soybean meal fermentation by lactobacillus plantarum P8 on growth, immune responses, and intestinal morphology in juvenile turbot (Scophthalmus maximus L.). Aquaculture. 2016; 464:87-94.

Wang Y, Li FG, Qin B, Chen J, Jiang XY, Zou SM. Duplicated connective tissue growth factor genes in hypoxia-sensitive blunt snout bream Megalobrama amblycephala and their in vivo expression. Comp Biochem Physiol Part - B Biochem Mol Biol. 2015;181:42-9. https://doi.org/10.1016/j.cbpb.2014.11.008.

Wei Y, Liang $\mathrm{M}, \mathrm{Xu} \mathrm{H}$, Zheng $\mathrm{K}$. Taurine alone or in combination with fish protein hydrolysate affects growth performance, taurine transport and metabolism in juvenile turbot (Scophthalmus maximus L.). Aquac Nutr. 2019;25:396-405. https://doi.org/10.1111/anu.12865.

Wilson RP, Poe WE. Effects of feeding soybean meal with varying trypsin inhibitor activities on growth of fingerling channel catfish. Aquaculture. 1985;46:19-25. https://doi.org/10.1016/0044-8486(85)90171-1.

Woo NYS. Metabolic and osmoregulatory changes during temperature acclimation in the red sea bream, Chrysophrys major: implications for its culture in the subtropics. Aquaculture. 1990;87:197-208. https://doi.org/10. 1016/0044-8486(90)90275-R.

Yu DH, Gong SY, Yuan YC, Lin YC. Effects of replacing fish meal with soybean meal on growth, body composition and digestive enzyme activities of juvenile Chinese sucker, Myxocyprinus asiaticus. Aquac Nutr. 2013;19:84-90. https://doi.org/10.1111/j.1365-2095.2012.00945.x.

Yuan LQ, Lu Y, Luo XH, Xie H, Wu XP, Liao EY. Taurine promotes connective tissue growth factor (CTGF) expression in osteoblasts through the ERK signal pathway. Amino Acids. 2007;32(3):425-30. https://doi.org/10.1007/s00726006-0380-4.

Zhang C, Rahimnejad S, Wang YR, Lu K, Song K, Wang L, et al. Substituting fish meal with soybean meal in diets for Japanese seabass (Lateolabrax japonicus): effects on growth, digestive enzymes activity, gut histology, and expression of gut inflammatory and transporter genes. Aquaculture. 2018a; 483:173-82. https://doi.org/10.1016/j.aquaculture.2017.10.029

Zhang J, Hu Y, Ai Q, Mao P, Tian Q, Zhong L, et al. Effect of dietary taurine supplementation on growth performance, digestive enzyme activities and antioxidant status of juvenile black carp (Mylopharyngodon piceus) fed with low fish meal diet. Aquac Res. 2018b;49:3187-95. https://doi.org/10.1111/are. 13783.

\section{Publisher's Note}

Springer Nature remains neutral with regard to jurisdictional claims in published maps and institutional affiliations.

Ready to submit your research? Choose BMC and benefit from:

- fast, convenient online submission

- thorough peer review by experienced researchers in your field

- rapid publication on acceptance

- support for research data, including large and complex data types

- gold Open Access which fosters wider collaboration and increased citations

- maximum visibility for your research: over $100 \mathrm{M}$ website views per year

At $\mathrm{BMC}$, research is always in progress.

Learn more biomedcentral.com/submissions 